\title{
PASSAGE TO MORE THAN IMAGISM: Whitman's Imagistic Poems
}

\author{
JOHN E. SCHWIEBERT
}

EVEN IN HIS EARLIEST NOTEBOOKS - for instance, in the pre-1855 unpublished poem "Pictures"-Whitman evinced a powerful interest in the pictorial aspect of poetry that was to remain with him throughout his career:

In a little house pictures I keep, many pictures hanging suspended-It is not a fixed house,

It is round-it is but a few inches from one side of it to the other side,

But behold! it has room enough - in it, hundreds and thousands, - all the varieties;

-Here! do you know this? This is cicerone himself;

... And there, on the walls hanging, portraits of women and men, carefully kept. ... ${ }^{1}$

In the 1856 "Spontaneous $\mathrm{Me}$ " $(L G, 103)$ he suggests that all poems are "merely pictures"; and in an 1871 note he asserts that "In these Leaves, every thing is literally photographed. Nothing is poetized, no divergence, not a step, not an inch, nothing for beauty's sake [sic] no euphemism, no rhyme." 2

It would be fatuous to suggest that "imagistic poems" make up an exclusive and distinctive subset of Leaves. Many passages from "Song of Myself" and other poems are as concentrated and pictorial as any of Whitman's short poems, and might stand as independent works. Yet there are some whole poems in which the discursive and didactic elements present in so many Whitman works are suppressed, and the visual element predominates. Without confusing them with the modern movement of that name, these poems can be described as "imagist." Like the poems of the modern Imagists, they are quintessentially short. They emphasize concentration and accuracy of vision. They are "structured by the single image or metaphor." They are, of course, in free verse ("nothing for beauty's sake no euphemism, no rhyme"). Finally, in their exact attention to the image, they refuse "to implicate the poem's effect in extended abstract meaning." 4 A poem like "The Runner" $(L G, 275)$ might well bear the subscript, "No ideas but in things."

On a flat road runs the well-train'd runner,

He is lean and sinewy with muscular legs, 
He is thinly clothed, he leans forward as he runs,

With lightly closed fists and arms partially rais'd.

Howard Waskow aptly calls such works poems of "non-direction." Whereas in didactic poems like "Starting from Paumanok" Whitman's poetic mask is fixed upon us, here it is averted. ${ }^{5}$ The speaker generally keeps himself out of the picture and does not "direct" us toward any particular message; there is no explanatory didacticism, no obtrusive persona telling us what or how to think. Images, "unclouded by rhetoric or sentiment" (Herbert Read's phrase), are presented objectively, to be experienced directly, in and of themselves, by the reader.

This "non-directive" persona is singularly appropriate to Whitman's democratic poetics, which maintain that readers-rather than the poet himself-are to "finish" the meaning of poems:

I round and finish little, if anything; and could not, consistently with my scheme. . . . I seek less to state or display any theme or thought, and more to bring you, reader, into the atmosphere of the theme or thought-there to pursue your own flight. ${ }^{6}$

. . . [T]he reader is to do something for himself, must be on the alert, must himself or herself construct indeed the poem . . . the text furnishing the hints, the clue, the start or frame-work. Not the book needs so much to be the complete thing, but the reader of the book does. ${ }^{7}$

To a far greater extent than the didactic poems, the imagist poems entrust the reader with the task of interpretation. Indeed, they virtually demand that the reader be "the poet's equal, a poet himself-perhaps, in fact, identical to the creator of the poem. . . ."

The imagist form is thus democratic in that it posits a relationship of relative equality between poet and reader. Significantly, it also assumes a particular kind of relationship between the reader and the subject(s) of the poem. This relationship is intimated in a remark Pound made about his "In a Station of the Metro," one of the most famous of modern Imagist poems. Pound wrote that his poem "is meaningless unless one has drifted into a certain vein of thought." The voyage metaphor is one Whitman would have appreciated. The reader is not a tabula rasa. On the contrary, readers are subjective beings with experiences, attitudes, knowledge, and emotions that they have inevitably accumulated in their own life journeys. Arriving at poem " $\mathrm{X}$," they are assumed to have prehistories in which they have "drifted" (thought, meditated, lived, and nourished themselves on Leaves) so that they will be in "a certain vein of thought" to catch its revelations. Otherwise, as Pound says, it will all be "meaningless."

Reading the poem is thus a kind of esthetic roulette, an all or nothing proposition: individual readers are either in a position to "get" the meanings or they are not. Alarmed at this uncompromising rhetor- 
ical situation, Howard Waskow has contended that Whitman had to find ways of mitigating the "problem" of "non-direction." 10 In fact, however, Whitman was not always so desperate to have his poems understood. Acknowledging no lukewarm readers, only lovers and strangers, he freely divides his audience into believers and non-believers, into those who will appreciate his poems and those who simply never will. $\mathrm{He}$ declines the role of apologist for his visions and views. His forthright dismissal of "a Certain Civilian" $(L G, 323)$ is characteristic:

What to such as you anyhow such a poet as I? therefore leave my works, And go lull yourself with what you can understand, and with piano-tunes, For I lull nobody, and you will never understand me.

Whitman's imagist poems, finally, are something of a paradox. Though among his most modest poems in size, they are (collectively) perhaps the most extravagant compliment he ever paid to the imaginations of his readers.

On my Northwest coast in the midst of the night a fishermen's group stands watching,

Out on the lake that expands before them, others are spearing salmon,

The canoe, a dim shadowy thing, moves across the black water,

Bearing a torch ablaze at the prow. ( $L G, 395)$

Unlike Whitman's more effusive works, such as "Song of Myself," this poem displays no discursive didacticism; it contains none of the syntactic polyphony, dilating rhetoric, or cumulative appositive phrasing that are the trademarks of the Whitmanian catalogic style. It seems neatly consistent with the stylistic norms advanced a half-century later by the Imagists in Some Imagist Poets (1915). It uses "common speech" in a free verse form; it presents an image that renders "particulars exactly"; it is "hard and clear"; and it displays that "concentration" which "is of the very essence of poetry." "The speaker's emotion is "objectified" in a few clear images: "a fishermen's group," the salmon spearers, a canoe, a torch. Verbs, lacking the modulations of tense common to longer Whitman poems, are reticently confined to the present participial and indicative forms ("watching," "are spearing," "Bearing," "stands," "expands," "moves").

Much has been said of Whitman's journey motif. Whitman views life as activity, energy, motion: "(All is a procession, / The universe is a procession with measured and perfect motion.)" ( $L G, 98)$. He repeatedly enjoins us to forgo rest and get on with the journey:

Allons! we must not stop here,

However sweet these laid-up stores, however convenient this dwelling we cannot remain here, 
However shelter'd this port and however calm these waters we must not anchor here, However welcome the hospitality that surrounds us we are permitted to receive it but a little while. $(L G, 154)$

Yet the poet of "Song of the Open Road," with its recurrent cry of "Allons!," is also the poet of unforgettable stops and pauses, of carefree idleness: "I stop somewhere waiting for you"; "I lean and loafe at my ease observing a spear of summer grass." $\mathrm{He}$ is the poet of insouciant stillness and intense vision, whose senses are alive to unnoticed miracles. Part of his role as lover and companion is to get us to see, also-not by abruptly collaring us, as he sometimes does in his didactic poems-but by seducing us, quietly, into rapt attention. He gives us a poem, and gets us to stay with it awhile. The image poem, which asks "to be read and re-read, to be meditated upon, until the full significance of the image [has] communicated itself," is a perfect medium for doing this. ${ }^{12}$

Like other of Whitman's imagist poems, "The Torch" invites us to linger, and thus to see. If it has any "lesson," that lesson is irreducible to content; it is the challenge, the test, of reading itself. The poem's title immediately invokes curiosity: where is this "torch"? what is its context? is it to be treated symbolically? What seems at first to be a simple "picture" turns out, on rereading, to be a picture within a picture. First, the speaker and reader look out on the scene the poem describes. Second, within the scene itself, "a fishermen's group stands watching." The object of this watching is disclosed in line two: speaker, reader, and "group" together look "Out on the lake that expands before them." From different perspectives they view the salmon spearers, and, less distinctly, the canoe the spearers float in, with its blazing torch.

The poem is arresting as a temporal experience. It gives us a sequence of images - the "coast," the "fishermen's group," the salmon spearers, etc. As none of these is esthetically complete in itself (e.g., we are impelled beyond the "fishermen's group" to discover what they are "watching"), we are drawn hastily on, line by line, through the unfolding scene until we arrive, in line four, at the "torch." The torch is the only image upon which the eye is allowed to rest. It is the poem's final focus. As we skip back to the title and reread the poem a second or third time (as we almost inevitably do-to sort out the rather complex relations of subject and object, to rediscover how it was that we got to that "torch," and simply to savor the image), the torch comes to be felt as increasingly central both to the completed picture and to our experience of it. The effect is like that of studying a painting in which all points in the plane direct us, intuitively, toward some focal, visually resonant figure or shape (Monet's "Impression, Sunrise" would be an example). Through the temporal process of reading and rereading, we arrive at a spatial perspective mimetic of the two-dimensionality of canvas. 
Whitman's imagist poems frequently edge into symbolism. This tendency in Whitman's poetic treatment of the image is echoed in comments he made on the treatment of images in the painting of his day. Matthiessen notes that Whitman retracted from the stark realism of his friend Thomas Eakins, finding the work of Jean Francois Millet more congenial. As distinct from realism in the raw, Millet's is a realism heightened by imagination to the heroic. His subjects-sowers, sawyers, gleaners, straw-binders, woodcutters-emerge less as particularized individuals than as broadly representative types of peasant or democratic virtues, such as tenacity, faith, simplicity, and courage. They are sowers and Sowers, gleaners and Gleaners, embodying those "ethic principles" Whitman regarded as central to great art. ${ }^{13}$

Millet's esthetic aims are helpful for understanding Whitman's own. A Millet biographer says the painter "wanted to make the beholder forget the painting and absorb the lesson."14 This sounds strikingly like Whitman admonishing himself to develop "A perfectly transparent, plate-glassy style . . .," in which the "picture" serves as a sort of "transparent" window-pane through which other meanings and "lessons" may be seen.

Often Whitman's imagist poems seem to point beyond themselves to broader spiritual realities. ". . . I see no object, no expression, no animal, no tree, no art, no book," the poet writes in his American Primer, "but I see, from morning to night, and from night to morning, the spiritual." 15 The poems become symbolic, achieving a "synthesis . . . between the concrete experience and its symbolic range" (Matthiessen, 616). Occasionally, Whitman himself hints at the symbolic nature of his images. In 1881 he placed the following piece, originally a Drum-Taps poem, among the cluster of "Inscriptions" that open Leaves.

Lo, the unbounded sea,

On its breast a ship starting, spreading all sails, carrying even her moonsails,

The pennant is flying aloft as she speeds she speeds so stately-below emulous waves press forward,

They surround the ship with shining curving motions and foam. ( $L G$, p. 12)

In his Walt Whitman (1883)-a work written in "virtual collaboration" with Whitman himself ${ }^{16}-$ R. M. Bucke describes the "Inscriptions" as "reflections upon" the "intention and meaning" of Leaves, thus plainly inviting a more than literal reading of the poem's central image. The thriving ship, with its inflated sails and lofty pennant, is meant to evoke the ruddy spirits of the poet himself as he launches his book-ship. This gloss is corroborated by Whitman himself in his own explanation of the poem as articulated by Bucke: 
The ship is the book, the ocean is the human mind. The large ship, with all sails set, starts on her voyage; as she presses through the water, the waves (the resistances the book meets) roll from her bows and down her sides. The angry, hostile criticisms and clamors are the bubbles of foam in the wake. ${ }^{17}$

"The Dismantled Ship" ( $L G, 534)$, originally published in 1888, when Whitman was four years from death and increasingly enfeebled, invites similarly autobiographical readings:

In some unused lagoon, some nameless bay,

On sluggish, lonesome waters, anchor'd near the shore,

An old, dismasted, gray and batter'd ship, disabled, done,

After free voyages to all the seas of earth, haul'd up at last and hawser'd tight,

Lies rusting, mouldering.

Of course (fortunately), Whitman did not always offer explicit glosses on the symbolism of his images, and generally his practice is closer to Pound's notion that "the natural object is always the adequate symbol." 18 The symbolism remains latent, oblique. Given the immense importance he attached to the Civil War, it is not surprising that the symbolic treatment of images should be especially rich in the Drum-Taps poems; for instance, in "An Army Corps on the March" (LG, 301):

With its cloud of skirmishers in advance,

With now the sound of a single shot snapping like a whip, and now an irregular

volley,

The swarming ranks press on and on, the dense brigades press on,

Glittering dimly, toiling under the sun-the dust-cover'd men,

In columns rise and fall to the undulations of the ground,

With artillery interspers' $\mathrm{d}-$ the wheels rumble, the horses sweat,

As the army corps advances.

The war constantly impressed Whitman with the democratic power and potential of the American people in the mass. In the bellicose poems that open Drum-Taps, images of the American democratic "En-Masse" recur. In the poet's fervently idealistic war (and postwar) vision, individuals and the collective-far from conflicting-are interdependent, each realizing itself fully in the other. "We shall," he writes in Democratic Vistas (1871),

... quickly and continually find the origin-idea of the singleness of man, individualism, asserting itself, and cropping forth, even from the opposite ideas. But the mass, or lump character, for imperative reasons, is to be ever carefully weigh'd, borne in mind, and provided for. Only from it, and from its proper regulation and potency, comes the other, comes the chance of individualism. ${ }^{19}$

The individual is actualized in the democratic comradeship of the enmasse, and the en-masse is symbolized and justified in sturdy, proud, 
self-sacrificing individuals. Thus in "Eighteen Sixty-One" the arming multitudes are personified as a single "strong man erect, clothed in blue clothes, advancing, carrying a rifle ..." $(L G, 282)$. In "Rise O Days from Your Fathomless Deeps" America, stung by secession, rises indignantly as one individual: "I have lived to behold man burst forth and warlike America rise . .." $(L G, 293)$. And as he symbolically rallies the Union troops, the poet-prophet revels in expressions of $e$ pluribus unum:

From Paumanok starting I fly like a bird,

Around and around to soar to sing the idea of all . . .

The idea of all, of the Western world one and inseparable,

And then the song of each member of these States. ( $L G, 284)$

The image that emerges from "An Army Corps on the March" is one of close-crowded toil and intensity, suggestive less of self-reliance than of mutual-reliance. The skirmishers form a "cloud"; members of the "corps" are in no way individualized. Their common strenuous effort envelops the marchers in a kind of human pressure-cooker: the ranks are "swarming," the brigades are "dense," "the horses sweat." The crucial characteristic of their progress-its relentlessness-is emphasized in verbal repetitions: they "press on and on," and again they "press on"; they "rise and fall to the undulations of the ground," which appears to stretch on interminably. This grand picture, in its sharp details and its cumulative effect, clearly excited Whitman. It suggests vividly those latent and immeasurable energies of the democratic mass that strive for expression, but die esthetically stillborn, in the sputtering exclamations of "Rise O Days from Your Fathomless Deeps": "Thunder on! stride on, Democracy! strike with vengeful stroke!" ( $L G, \mathrm{p}$. 292, line 33).

Crucially, this vignette of mass and movement is open-ended. It breaks in (like so many Drum-Taps poems) on a slice of action in medias res. Where did these "ranks" come from? Where are they heading, and what is to happen to them? Such questions lie well outside the "frame" of this picture, which in no way invites us to think about them. Climactic actions and battles clearly interest this poet far less then do the energies behind them. In its very intensive focus, glancing neither to future nor past, the poem virtually implies that it is those energies that have never been adequately depicted, by anyone, through centuries and centuries of poems about pitched battles and victories; and, if marchers have been 'sketched,' certainly no one has drawn these democratic troops, who are new to history, and of the future. The poem restricts our attention to the subject of movement, the significance of which is limited only by the reader's imagination. It may be a military march we are observing; it may, in addition, be a spectacle akin to the cosmic swell and progress evoked in "Pioneers! O Pioneers!," in which are seen 
advancing "the youthful sinewy races" (line 7). Though imagism is not his interest, George B. Hutchinson neatly illuminates Whitman's imagistic technique when he characterizes poems like "An Army Corps" as "snapshots of sacred events." 20

Whitman's poetry is characteristically "I"-centered (in addition to being, especially and most overtly in the earlier poems, "you"centered). But what happens to the "I" in the image poems? Does he simply disappear? The assumption that poetry is subjective was so central to the modern Imagists that Hulme, prophet of the new school, compared Imagism and modern free verse generally to French Impressionist painting. ${ }^{21}$ Most modern Imagists, however, wanted subjective feelings and attitudes to be implied in images themselves rather than by discursive elaborations. Thus F. S. Flint characteristically calls for "Direct treatment of the 'thing,' whether subjective or objective."22 Whitman, too, repeatedly insists that readers "see" the world directly for themselves, and not at second-hand through the poet's eyes: "You shall not look through my eyes, nor take things from me. . . ." Yet even in his most concentrated visual vignettes, Whitman seems to have achieved (or perhaps desired) such self-effacement less often than is sometimes supposed. In fact, those short poems of Whitman's that emphasize the concrete specific image also commonly project-albeit subtly - the face and personality of the poet.

"A Farm Picture" ( $L G, 274)$ illustrates:

Through the ample open door of the peaceful country barn,

A sunlit pasture field with cattle and horses feeding,

And haze and vista, and the far horizon fading away.

Here we regard a pleasant pastoral scene from what is clearly the speaker's point of view, as he stands behind "the ample open door." As striking as the image itself is the subjectivity through which we perceive it. Whitman subtly emphasizes that this is not simply a scene existing $a$ priori-and hence separately from the experiencing, apperceptive persona-but inseparably (and, one ventures, miraculously) enfolded in the experiencing consciousness. It is a scene that he, a person, is seeing for himself as he stands in a particular place. More interestingly, while implying his own presence, Whitman omits any explicit reference to it: first person pronouns are conspicuously absent. By inference, the view is not possessively and exclusively his, but a democratic dispensation of nature, one in which we are tacitly invited to participate ourselves. Indeed, as we read and reflect, we seem to occupy the doorway space as much as does the great Camerado (who might imagine himself resting 
against the doorjamb, with one arm insouciantly draping you or me, the reader). The view is democratic, as much ours as his.

Matthiessen likened Whitman's image poems to nineteenth-century genre painting. Impressionism, with its delight in subjectivity, offers another suggestive analogy from painting-though there is no evidence that the French painters influenced Whitman, and the Impressionists' pleasure in visual sensation for its own sake (without guiding "ethic principles") certainly would have displeased the poet, who preferred the more morally expressive art of Millet. A point of contrast is also illuminating: the Impressionist specializes in evanescence, in capturing bodily arrangements, color-tones, and light and scenes - a sunrise, a slice of human action-that will change in an instant's time, never to recur in exactly the same way. Monet's "Haystacks," arresting a dozen impressions of the infinitely variable effects of light and season on one scene, are a good example. By contrast, Whitman's "vista," in its full ripeness and largesse, and its temporal indefiniteness (season and time of day are unspecified) will remain liberally before viewers for a long time, for as long as they choose to live inside this poem. While the Impressionist focuses attention on the fleeting, Whitman rivets his-and ours-on what is permanent and lasting.

The interplay of poet and environment is manifest again in "Sparkles from the Wheel" ( $L G, 389$ ), a poem of Whitman's later years (1871). In a context of hurried and never-ending movement (the restless surge of the modern metropolis, "Where the city's ceaseless crowd moves on the livelong day") the poet is "Withdrawn": ". . . I join a group of children watching, I pause aside with them." The speaker is mentally seized, along with the children, not by any extraordinary occurrence but by an everyday scene-or more accurately, an everyday activity: the simple, routine labor of a knife-grinder working "By the curb toward the edge of the flagging." While the distracted motions of the city careen and whirl all around them, everyone in this spontaneously formed and suddenly intimate cluster is intensely concentrating: the children and speaker on the knife-grinder, the latter on his work. The speaker, lone adult among children, watches like a child. So rapt is his attention that he responds to every detail, gross and minute, of the workman's movement-from the fact of the work itself (line 4) to the velocity at which the wheel revolves (line 6). He even registers the exact pressure of the hand and knife ("light but firm") against the wheel. In the intensity of the moment, any retrospective, hierarchic ordering of sensory experience is precluded; no one detail supersedes the others, and each elicits an equally intense and vital response:

A knife-grinder works at his wheel sharpening a great knife,

Bending over he carefully holds it to the stone, by foot and knee,

With measur'd tread he turns rapidly, as he presses with light but firm hand. . . . 
Then, in the last two lines of the stanza, an image appears that supersedes, slightly but unmistakably, the others, and brings them into a sudden focus that is more than visual:

Forth issue then in copious golden jets, Sparkles from the wheel.

The image is climactic, both for its visual scintillation and because it is the demonstrable result of all the grinder's concentrated and measured effort-and, it almost seems, of the onlookers' concentrated attention. Esthetically speaking, the sparkles make things happen. Without them the children do not pause to form their "group"; the poet doesn't put off his plans to stop at the edge of the flagging and look; and "the city's ceaseless crowd," for lack of contrast to this quietly brilliant spectacle, is just noise and distraction, never esthetically objectified. Lacking the "sparkles," the accumulating pressures of the preceding lines would be so much strain without accomplishment, lovemaking without orgasm, labor without childbirth. The sparkles "issue" forth, and everything, far and near, aural and visual and tactile-from the harried footsteps of the enveloping traffic to the children, from the sounds of the street to the sounds of the revolving wheel and the look of the old man's chinsuddenly "connects":

The scene and all its belongings, how they seize and affect me,

The sad sharp-chinn'd old man with worn clothes and broad shoulder-band of leather, Myself effusing and fluid, a phantom curiously floating, now here absorb'd and

arrested,

The group, (an unminded point set in a vast surrounding,)

The attentive, quiet children, the loud, proud, restive base of the streets,

The low hoarse purr of the whirling stone, the light-press'd blade,

Diffusing, dropping, sideways-darting, in tiny showers of gold,

Sparkles from the wheel.

Any frame around this picture would have to be exceedingly large. The "picture" we see does not border out at the speaker; nor does it stop at the speaker and the "group" of children, nor even at the speaker, group, and knife-grinder with his wheel. It keeps expanding, circle on circle, outward, to encompass the busy streets (which are no less visualized for being cursorily mentioned) and, metaphorically, the whole busy, hustling, dynamic world (the "vast surrounding"). Images seemingly unrelated - a quietly concentrating craftsman and a teeming and restless populace-momentarily interlock, moving to a single pattern, a single dance. The creator of this dance is the subjective consciousness of the poet. Both in the scene and outside it, he is acutely aware of the compositional influence he exerts on the immediate scene, 
of the effect his vision has on what he sees: "Myself effusing and fluid, a phantom curiously floating, now here absorb'd and arrested. . .."

Rhythm-many kinds of it-permeates this brief poem: the rhythms of words, of sensory impressions, people, movements. These flow together in the wheel, perennial symbol of unity and regeneration. (The symbol appears again, in drastically different context, in "The Dalliance of the Eagles," where mating eagles form "a living, fierce, gyrating wheel.") The poem locates us in radically different physical surroundings from "Song of Myself," Section 6, with its grassy fields. Yet it places us in the same locale transcendentally: the place of epiphanies. In Eliot's phrase, it captures a moment in which "all time" is felt as "eternally present."

In a note on an 1848 article about "Indian Epic Poetry" Whitman writes, "The style of a great poem must flow on "unhasting and unresting.' "23 In fact, the nearly 400 poems of the 1891-1892 Leaves of Grass and its annexes seem to keep readers alertly oscillating between extremes of haste and rest. Where the long catalog poems hurry us along-with often dazzling rapidity-through a panoramic range of pictorial details, scenes, and experiences, the brief image poems invite us to linger at length over a few lines. Despite their slightness on the printed page (and to some extent because of it), they tax reader attentiveness and imagination. Perhaps, as Whitman hoped, they embody an ideal of his democratic poetics by making us "poets" ourselves; for they invite us to limn significances (as poets do) behind even the most overtly "simple" and "objective" facts. In the process, they also return us, as often as not, to the perennial focus of Leaves - Walt Whitman himself. The poet-rough who challenges himself, in "Song of Myself," to "let it [himiself] out" (line 568) is here at his most restrained. Yet even in these most "objective" of his poems, Whitman's presence and personality distinctly shine.

\section{Weber State College}

\section{NOTES}

1 Leaves of Grass, Comprehensive Reader's Edition, ed. Harold W. Blodgett and Sculley Bradley (New York: New York University Press, 1965), 642. Herafter LG.

2 Notebooks and Unpublished Prose Manuscripts, ed. Edward F. Grier (New York: New York University Press, 1984), 4:1523-1524.

3 The Imagists' ambivalence about Whitman is discussed by Howard J. Waskow in Whitman: Explorations in Form (Chicago: University of Chicago Press, 1966), 110-111. Pound's war and "pact" with Whitman are well known. While respecting the groundbreaking role of his free verse (as opposed to its craft and technique), Imagist poets and propogandists - with their demand that poetry exhibit concentrated form-objected to Whitman's expansive rhetoric and frequent didacticism. Typical is the implied criticism 
of America's "cosmic poet" in the Preface to the first anthology of Some Imagist Poets (1915):

We are not a school of painters, but we believe that poetry should render particulars exactly and not deal in vague generalities, however magnificent and sonorous. It is for this reason that we oppose the cosmic poet, who seems to us to shirk the real difficulties of his art.

4 Stanley K. Coffman, Jr., "Imagism," Princeton Encyclopedia of Poetry and Poetics, ed. Alex Preminger et al., enl. ed. (Princeton: Princeton University Press, 1974), 377.

5 Waskow, 108-109.

6 Prose Works, 1892, ed. Floyd Stovall (New York: New York University Press, 1963-1964), 2:725.

7 Prose Works, 2:425.

8 Waskow, 109. Whitman criticizes traditional poetry for minimizing (in his view) the role of the reader in the poem. Representing a "feudal" or "caste" society, the poet of tradition advances aristocratic values and ideals and proffers "finished" poems for the reader to accept and appreciate passively, as a kind of entertainment. In contrast, Whitman stresses that "modern" poetry (i.e., his own) establishes a dynamically interactive relationship among poet, poem, and reader. Rather than dictating "truths" in "finished" poems, the poet-a comrade among comrades - invites the reader's imaginative and empathic participation in the poem. See Donald D. Kummings, "Walt Whitman's Vernacular Poetics," The Canadian Review of American Studies 7 (Fall 1976), 119-131.

9 "Vorticism," Fortnightly Review, 1 September 1914, 467.

10 Waskow, 109-110.

11 My quotations are extracted from the six rules of Imagism set forth in the 1915 Preface. See Stanley K. Coffman, Jr., Imagism: A Chapter for the History of Modern Poetry (Norman: University of Oklahoma Press, 1951), 28-29.

1. To use the language of common speech, but to employ always the exact word, not the nearly-exact, nor the merely decorative word.

2. To create new rhythms - as the expression of new moods - and not to copy old rhythms, which merely echo old moods. . . .

3. To allow absolute freedom in the choice of subject. . . .

4. To present an image (hence the name: "Imagist"). We are not a school of painters, but we believe that poetry should render particulars exactly and not deal in vague generalities, however magnificent and sonorous. . . .

5. To produce poetry that is hard and clear, never blurred nor indefinite.

6. Finally, most of us believe that concentration is of the very essence of poetry.

12 See William Pratt, ed., The Imagist Poem: Modern Poetry in Miniature (New York: Dutton, 1963), 30.

13 F. O. Matthiessen, American Renaissance: Art and Expression in the Age of Emerson and Whitman (1941; rpt. London: Oxford University Press, 1974), 602, 613; Prose Works, 2:420.

14 Percy M. Turner, Millet (London: T. C. \& E. C. Jack, n.d.), 28.

15 An American Primer by Walt Whitman: With Facsimiles of the Original Manuscript, ed. Horace Traubel (1904; rpt. Stevens Point, WI: Holy Cow! Press, 1987), 1. 
16 Daniel Maggin, foreword, Walt Whitman's Autograph Revision of the Analysis of Leaves of Grass (New York: New York University Press, 1974), 7-9.

17 R. M. Bucke, Walt Whitman's Autograph Revision of the Analysis of Leaves of Grass, 72.

18 “A Few Don'ts by an Imagiste," Poetry (March 1913), 201.

19 Prose Works, 2:373.

20 The Ecstatic Whitman: Literary Shamanism and the Crisis of the Union (Columbus: Ohio State University Press, 1986), 143.

21 "A Lecture on Modern Poetry," in Further Speculations, ed. Sam Hynes (Minneapolis: University of Minnesota Press, 1955), 72.

22 "Imagisme," Poetry (March 1913), 199.

23 Quoted in Floyd Stovall, The Foreground of Leaves of Grass (Charlottesville: University Press of Virginia, 1974), 166. 